University of New Hampshire

University of New Hampshire Scholars' Repository

\title{
$5-2002$
}

\section{Shouldn't snowpacks be sources of monocarboxylic acids?}

Jack E. Dibb

University of New Hampshire, jack.dibb@unh.edu

Matthew Arsenault

University of New Hampshire - Main Campus

Follow this and additional works at: https://scholars.unh.edu/earthsci_facpub

Part of the Atmospheric Sciences Commons

\section{Recommended Citation}

Jack E. Dibb, Matthew Arsenault, Shouldn't snowpacks be sources of monocarboxylic acids?, Atmospheric Environment, Volume 36, Issues 15-16, May-June 2002, Pages 2513-2522, ISSN 1352-2310, http://dx.doi.org/10.1016/S1352-2310(02)00131-0.

This Article is brought to you for free and open access by the Earth Sciences at University of New Hampshire Scholars' Repository. It has been accepted for inclusion in Earth Sciences Scholarship by an authorized administrator of University of New Hampshire Scholars' Repository. For more information, please contact Scholarly.Communication@unh.edu. 


\title{
Measurements of pernitric acid at the South Pole during ISCAT 2000
}

\author{
D. L. Slusher, ${ }^{1}$ L. G. Huey, ${ }^{1,2}$ D. J. Tanner, ${ }^{1}$ G. Chen, ${ }^{1}$ D. D. Davis, ${ }^{1}$ M. Buhr, ${ }^{1}$ \\ J. B. Nowak, ${ }^{1,3}$ F. L. Eisele, ${ }^{1,4}$ E. Kosciuch, ${ }^{4}$ R. L. Mauldin, ${ }^{4}$ B. L. Lefer, ${ }^{4}$ \\ R. E. Shetter, ${ }^{4}$ and J. E. Dibb ${ }^{5}$ \\ Received 19 June 2002; revised 13 September 2002; accepted 13 September 2002; published 2 November 2002.
}

[1] The first measurements of pernitric acid at the South Pole were performed during the second Investigation of Sulfur Chemistry in the Antarctic Troposphere (ISCAT 2000). Observed $\mathrm{HO}_{2} \mathrm{NO}_{2}$ concentrations averaged 25 pptv. Simple steady-state calculations constrained by measurements show that the lifetime of pernitric acid was largely controlled by dry deposition, with thermal decomposition becoming increasingly important at warmer temperatures. We determined that the pernitric acid equilibrium constant is less uncertain than indicated in the literature. One consequence of pernitric acid deposition to the snow surface is that it is an important sink for both $\mathrm{NO}_{\mathrm{x}}$ and $\mathrm{HO}_{\mathrm{x}}$. Another is that the photochemistry of $\mathrm{HO}_{2} \mathrm{NO}_{2}$ in the Antarctic snowpack may be a $\mathrm{NO}_{\mathrm{x}}$ source in addition to nitrate photolysis. This might be one of the important differences in snow photochemistry between the South Pole and warmer polar sites. INDEX TERMS: 0365 Atmospheric Composition and Structure: Tropospherecomposition and chemistry. Citation: Slusher, D. L., L. G. Huey, D. J. Tanner, G. Chen, D. D. Davis, M. Buhr, J. B. Nowak, F. L. Eisele, E. Kosciuch, R. L. Mauldin, B. L. Lefer, R. E. Shetter, and J. E. Dibb, Measurements of pernitric acid at the South Pole during ISCAT 2000, Geophys. Res. Lett., 29(21), 2011, doi:10.1029/2002GL015703, 2002.

\section{Introduction}

[2] Atmospheric pernitric acid is formed via the association reaction of $\mathrm{NO}_{2}$ with $\mathrm{HO}_{2}$ [Niki et al., 1977]. Loss pathways include thermal decomposition, photolysis, reaction with $\mathrm{OH}$, and dry deposition.

$$
\begin{gathered}
\mathrm{HO}_{2}+\mathrm{NO}_{2}+\mathrm{M} \leftrightarrow \mathrm{HO}_{2} \mathrm{NO}_{2}+\mathrm{M} \\
\mathrm{HO}_{2} \mathrm{NO}_{2}+\mathrm{h} \nu \rightarrow \text { products } \\
\mathrm{OH}+\mathrm{HO}_{2} \mathrm{NO}_{2} \rightarrow \mathrm{H}_{2} \mathrm{O}+\mathrm{NO}_{2}+\mathrm{O}_{2} \\
\mathrm{HO}_{2} \mathrm{NO}_{2} \rightarrow \text { deposition }
\end{gathered}
$$

\footnotetext{
${ }^{1}$ School of Earth and Atmospheric Sciences, Georgia Institute of Technology, Atlanta, Georgia, USA.

${ }^{2}$ School of Chemistry and Biochemistry, Georgia Institute of Technology, Atlanta, GA, USA.

${ }^{3}$ Now an NRC Research Associate at Aeronomy Laboratory, NOAA, Boulder, CO, USA.

${ }^{4}$ Atmospheric Chemistry Division, National Center for Atmospheric Research, Boulder, Colorado, USA.

${ }^{5}$ Climate Change Research Center, Institute for the Study of Earth, Oceans, and Space, University of New Hampshire, Durham, New Hampshire, USA.
}

Copyright 2002 by the American Geophysical Union. 0094-8276/02/2002GL015703
Uncertainties in the $\mathrm{HO}_{2} \mathrm{NO}_{2}$ equilibrium constant $\left(\mathrm{K}_{\mathrm{eq}}=\right.$ $\left.\mathrm{k}_{(1)} / \mathrm{k}_{(-1)}\right)$ and absorption cross-section at long wavelengths have fueled recent speculation, often conflicting, in the literature about pernitric acid's roles as a radical source and sink in the upper atmosphere [Wennberg et al., 1999; Brune et al., 1999; Jaeglé et al., 2001]. The discovery of elevated $\mathrm{NO}_{\mathrm{x}}$ levels at Summit, Greenland; Alert, Canada; Neumayer Station in Antarctica; and the South Pole [Honrath et al., 1999; Ridley et al., 2000; Jones et al., 2000; Davis et al., 2001] indicates that $\mathrm{HO}_{2} \mathrm{NO}_{2}$ may also play an important role in the low altitude photochemistry of polar regions.

[3] One interesting feature of the South Pole is that the average NO level (based on 1998 and 2000 ISCAT observations) is nearly ten times larger than that observed at any of the other polar stations. These high $\mathrm{NO}_{\mathrm{x}}$ levels along with very cold temperatures make the South Pole an ideal place to study pernitric acid. Modeling results from the 1998 ISCAT study predicted that pernitric acid is the second most important $\mathrm{HO}_{\mathrm{x}}$ sink at the South Pole, behind $\mathrm{HNO}_{3}$, by way of dry deposition and reaction with $\mathrm{OH}$ [Chen et al., 2001]. It follows that dry deposition of pernitric acid should also be an important $\mathrm{NO}_{\mathrm{x}}$ sink in this environment. Presented here is an analysis of pernitric acid measurements made at the South Pole during ISCAT 2000.

\section{Methods}

[4] $\mathrm{HO}_{2} \mathrm{NO}_{2}$ and $\mathrm{HNO}_{3}$ were detected using the $\mathrm{SF}_{6}^{-}$ chemical ionization mass spectrometry (CIMS) technique described in detail by Slusher et al. [2001]. The instrument is essentially identical to the one described by Leibrock and Huey [2000]. Measurements were made from the second floor of the Atmospheric Research Observatory (ARO). The CIMS inlet was located $10 \mathrm{~m}$ above the snow extending $0.25 \mathrm{~m}$ beyond the outer wall of the ARO facing prevailing winds from the clean air sector $(0-$ $120^{\circ}$ longitude)

[5] The $\mathrm{HO}_{2} \mathrm{NO}_{2}$ sensitivity was typically $2.0 \mathrm{~Hz} / \mathrm{pptv}$ at $2 \mathrm{MHz}$ of reagent ion signal, and the detection limit was 5 pptv for data averaged over $1 \mathrm{~min}$. The detection limit is based on a signal-to-noise ratio of 3:1 where the noise is the standard deviation of the background counts. Pernitric acid was measured between $12 / 18 / 00$ and 12/28/00. Simultaneous measurements of $\mathrm{NO}, \mathrm{OH}, \mathrm{O}_{3}$, actinic fluxes, and meteorological parameters were performed as in the ISCAT 1998 campaign [Davis et al., 2001; Mauldin et al., 2001; Lefer et al., 2001]. The $\mathrm{OH}$ instrument was switched to $\left(\mathrm{HO}_{2}+\mathrm{RO}_{2}\right)$ measurement mode on several occasions employing the CIMS procedure described by Cantrell et al. [1997]. This method converts $\mathrm{HO}_{2}$ and $\mathrm{RO}_{2}$ to $\mathrm{OH}$ via addition of NO. 


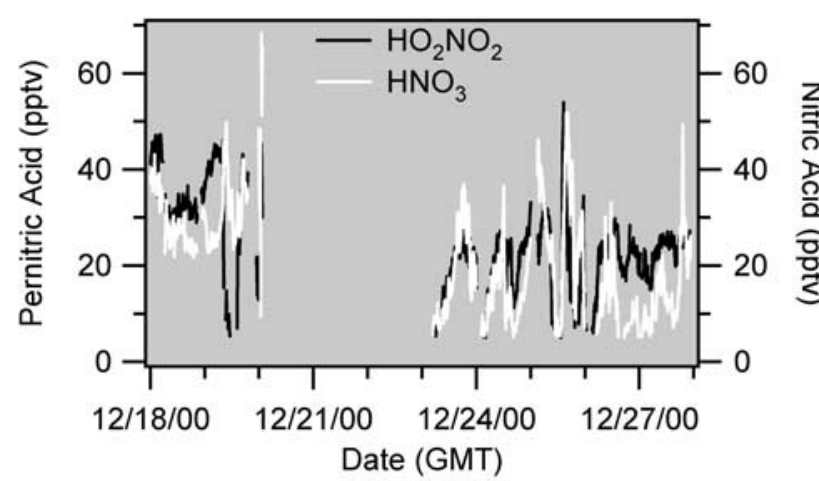

Figure 1. Measured pernitric acid and nitric acid. All data has been averaged for $10 \mathrm{~min}$. No data is available for $12 / 20 / 00-12 / 22 / 00$ due to snow sampling experiments.

[6] $\mathrm{NO}_{2}$ mixing ratios were derived from steady-state calculations utilizing measurements of $\mathrm{NO}, \mathrm{O}_{3}$, photolysis frequencies, and a combination of measured and estimated $\mathrm{HO}_{2}$ and $\mathrm{CH}_{3} \mathrm{O}_{2}$. We assumed $\mathrm{CH}_{3} \mathrm{O}_{2}$ was the only $\mathrm{RO}_{2}$ species of significant concentration. The $\left(\mathrm{HO}_{2}+\mathrm{RO}_{2}\right)$ data is limited because it and $\mathrm{OH}$ could not be measured simultaneously. Therefore, a method for estimating $\mathrm{HO}_{2}$ and $\mathrm{CH}_{3} \mathrm{O}_{2}$ during $\mathrm{OH}$ measurements was devised. The fractional $\mathrm{CH}_{3} \mathrm{O}_{2}$ contribution to $\left(\mathrm{HO}_{2}+\mathrm{RO}_{2}\right)$ calculated by a full photochemical box model [Chen et al., 2001] was used to extract standalone experimental $\mathrm{CH}_{3} \mathrm{O}_{2}$ and $\mathrm{HO}_{2}$ mixing ratios from the $\left(\mathrm{HO}_{2}+\mathrm{RO}_{2}\right)$ measurements. The average $\mathrm{CH}_{3} \mathrm{O}_{2} /\left(\mathrm{HO}_{2}+\mathrm{RO}_{2}\right)$ was 0.22 with a range of 0.18 to 0.28 . The ratios of $\mathrm{HO}_{2} / \mathrm{OH}$ and $\mathrm{CH}_{3} \mathrm{O}_{2} / \mathrm{OH}$ were fit as functions of $\mathrm{NO}$ to generate predicted $\mathrm{HO}_{2}$ and $\mathrm{CH}_{3} \mathrm{O}_{2}$ values during $\mathrm{OH}$ measurement periods. The median predicted $\mathrm{HO}_{2}$ and $\mathrm{CH}_{3} \mathrm{O}_{2}$ matched experimental values within $8 \%$. Of 159 data pairs, 156 predicted $\mathrm{HO}_{2}$ values and 157 predicted $\mathrm{CH}_{3} \mathrm{O}_{2}$ values were within $50 \%$ of the corresponding experimental values. Consequently, the overall uncertainty of the model predicted concentrations is essentially the same as the $\left(\mathrm{HO}_{2}+\mathrm{RO}_{2}\right)$ measurement error of $\pm 60 \%$. The mean $\left[\mathrm{NO}_{2}\right] /[\mathrm{NO}]$ was 0.44 . Reaction of $\mathrm{NO}$ with $\mathrm{O}_{3}, \mathrm{HO}_{2}$, and $\mathrm{CH}_{3} \mathrm{O}_{2}$ contributed $86 \%, 11 \%$, and $3 \%$ respectively to the total ratio.

\section{Results and Analysis}

[7] All statistics and analyses are based on $10 \mathrm{~min}$ data averages, and only data above established detection limits for each measurement are included. Pernitric acid mixing ratios ranged from $<5$ to 54 pptv (mean 25 pptv, median 24 pptv) during the measurement period compared with $<5$ to 68 pptv (22 pptv mean and median) of nitric acid. See Figure 1 for a time series of both species. The total estimated uncertainty is $\pm 50 \%$ for $\mathrm{HO}_{2} \mathrm{NO}_{2}$ and $\pm 30 \%$ for $\mathrm{HNO}_{3}$. $\mathrm{NO}$ and $\mathrm{O}_{3}$ mixing ratios averaged 115 pptv and 31 ppbv respectively. The mean dew point was $-30.9^{\circ} \mathrm{C}$ with a range of $-36.0^{\circ} \mathrm{C}$ to $-26.5^{\circ} \mathrm{C}$ while temperatures ranged from $-31.5^{\circ} \mathrm{C}$ to $-23.6^{\circ} \mathrm{C}$ and averaged $-27.7^{\circ} \mathrm{C}$.

[8] In order to analyze the pernitric acid measurements, $\mathrm{HO}_{2} \mathrm{NO}_{2}$ concentrations were predicted from reactions (1)(3) assuming that steady state was achieved. The $\mathrm{HO}_{2} \mathrm{NO}_{2}$ model was constrained by measured $\mathrm{NO}, \mathrm{OH}, \mathrm{O}_{3}$, pressure, and temperature; experimental and estimated $\mathrm{HO}_{2}$; and calculated $\mathrm{NO}_{2}$. The J-value for pernitric acid was derived by combining the measured UV photolysis rate with an estimate of the near-IR photodissociation rate of $1 \times 10^{-5}$ $\mathrm{s}^{-1}$ [Roehl et al., 2002]. The resulting average J-value was $1.6 \times 10^{-5} \mathrm{~s}^{-1}$ (with a constant solar zenith angle of $\sim 67^{\circ}$ ). This corresponds to a photolysis lifetime of $17.4 \mathrm{hr}$, which contributes little to the average total $\mathrm{HO}_{2} \mathrm{NO}_{2}$ lifetime of 1.7 $\mathrm{hr}$ obtained by dividing the measured concentrations by the instantaneous production rate $\left(\mathrm{P}_{\mathrm{HO} 2 \mathrm{NO} 2}=\mathrm{k}_{(1)}\left[\mathrm{HO}_{2}\right]\left[\mathrm{NO}_{2}\right]\right)$.

[9] Figure 2 compares the pernitric acid measurements and the calculated production rate. The $\mathrm{HO}_{2} \mathrm{NO}_{2}$ production rate is also presented versus temperature for reference. The fact that $\left[\mathrm{HO}_{2} \mathrm{NO}_{2}\right]$ remains essentially flat at production rates above $20 \mathrm{pptv} / \mathrm{hr}$, corresponding to colder temperatures, is contrary to loss controlled by thermal decomposition. As temperature decreases, $\mathrm{P}_{\mathrm{HO} 2 \mathrm{NO} 2}$ tends to increase because $\left[\mathrm{NO}_{\mathrm{x}}\right]$ also increases (Figure 2 bottom panel); however, the $\mathrm{NO}_{\mathrm{x}}$ flux measured from the snow appears
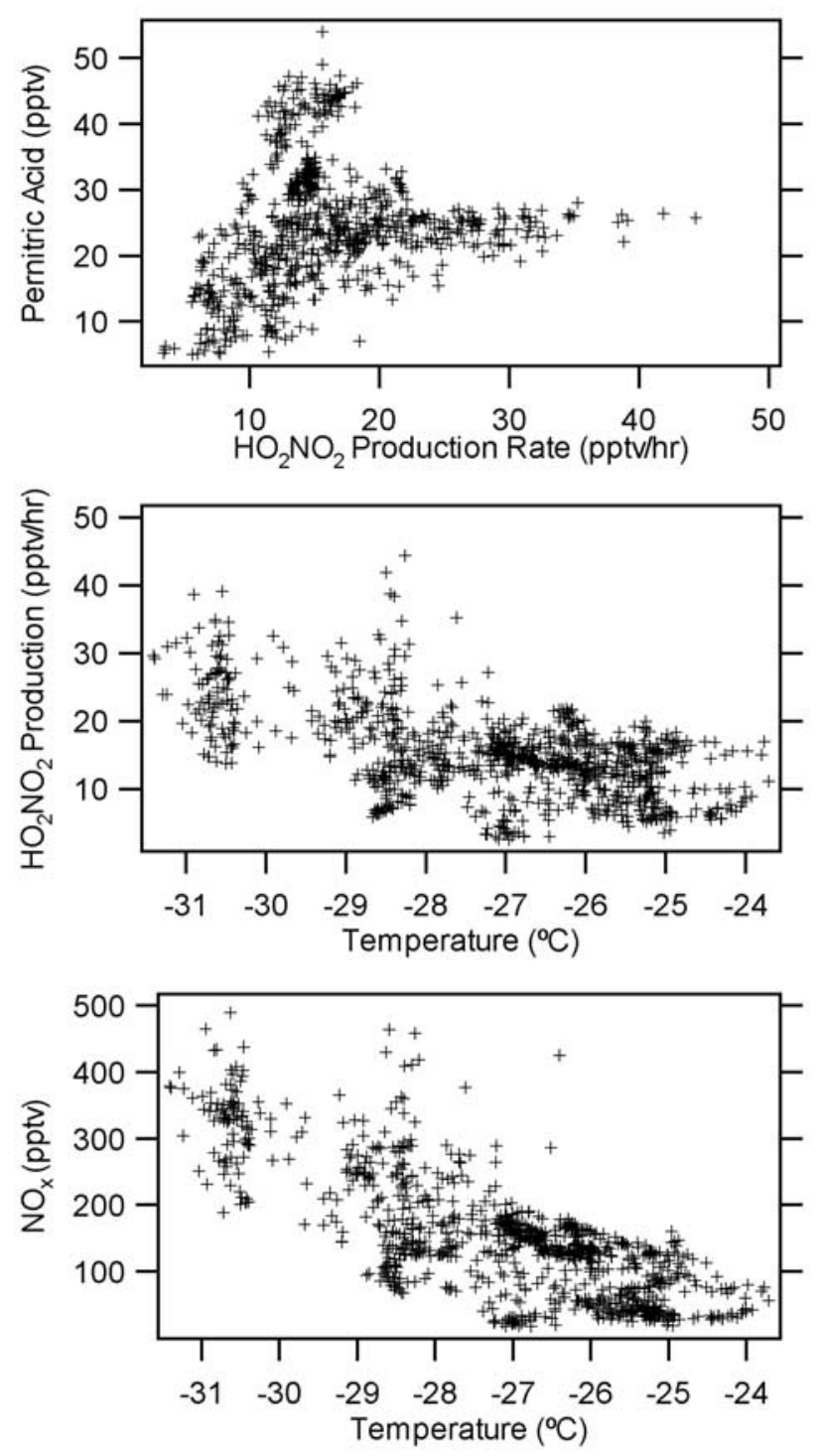

Figure 2. Measured pernitric acid concentration, pernitric acid production rate, temperature measured at $1.6 \mathrm{~m}$, and $\mathrm{NO}_{\mathrm{x}} \cdot \mathrm{NO}_{\mathrm{x}}=$ measured $\mathrm{NO}+$ modeled $\mathrm{NO}_{2}$. 


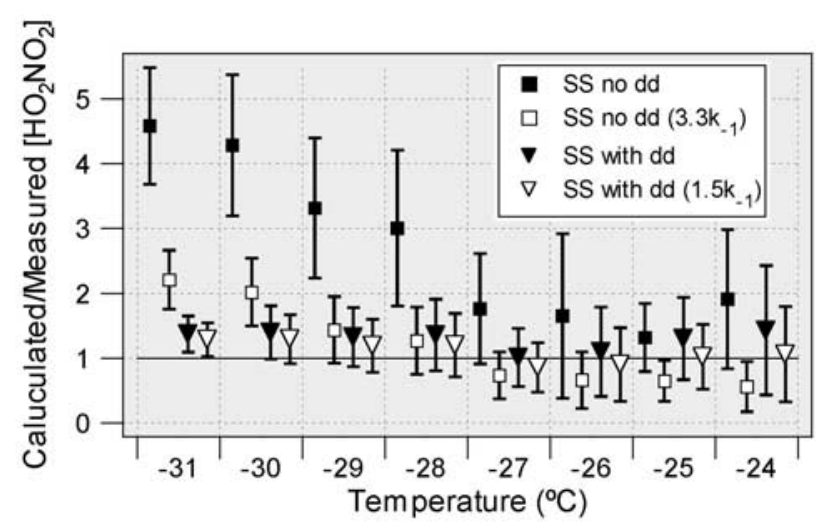

Figure 3. Comparison of pernitric acid measurements with calculations. SS indicates steady state and dd represents dry deposition. The various calculations were performed with $\mathrm{k}_{(-1)}$ derived from DeMore et al. [1997], $\mathrm{k}_{(-1)}$ multiplied by 3.3 , and $\mathrm{k}_{(-1)}$ multiplied by 1.5 as noted. Symbols represent the mean at each temperature and error bars span \pm 1 standard deviation.

to be constant $\pm 30 \%$ [Davis et al., in preparation]. This indicates that the mixing depth decreases with decreasing temperature, allowing for the buildup of $\mathrm{NO}_{\mathrm{x}}$ released from the snowpack. It follows that the atmospheric pernitric acid concentration will decrease via deposition more rapidly at the colder temperatures associated with lower mixed layer heights.

[10] Figure 3 shows that measured pernitric acid levels were much lower than predicted by the simple steady-state model without dry deposition, suggesting that an important loss process is missing from the model. Better agreement can be obtained by reducing the equilibrium rate coefficient, adding dry deposition, or both. At $-28^{\circ} \mathrm{C}$, the uncertainty in $\mathrm{K}_{\mathrm{eq}}$ is a factor of 10.3 [DeMore et al., 1997]. This is primarily due to the uncertainty in $\mathrm{k}_{(-1)}$ because the forward rate coefficient is well characterized [DeMore et al., 1997]. The $\mathrm{HO}_{2} \mathrm{NO}_{2}$ thermal decomposition rate coefficient used by DeMore et al. [1997] to calculate $\mathrm{K}_{\mathrm{eq}}$ is based solely on an extrapolation of the results obtained by Graham et al. [1977] between $-19^{\circ} \mathrm{C}$ and $10^{\circ} \mathrm{C}$ at $1 \mathrm{~atm}$. The expression $\mathrm{k}_{(-1)}=4.13 \times 10^{-13} \mathrm{e}^{(-20134 / \mathrm{RT})}$ was derived for the thermal decomposition rate coefficient at $700 \mathrm{mb}$ from the DeMore et al. [1997] recommended values for $\mathrm{K}_{\mathrm{eq}}$ and $\mathrm{k}_{(1)}$.

[11] Changing $\mathrm{k}_{(-1)}$ so that predicted $\mathrm{HO}_{2} \mathrm{NO}_{2}$ levels agree well with measurements at a particular temperature without any dry deposition results in overprediction at lower temperatures and underprediction at higher temperatures (e.g., SS no dd $\left(3.3 \mathrm{k}_{-1}\right)$ in Figure 3). A similar result is obtained when a constant loss due to dry deposition is used with no modification to $\mathrm{k}_{(-1)}$. Applying dry deposition as a function of temperature, however, produces much better results. Therefore, we hypothesized that both dry deposition and an adjustment to $\mathrm{k}_{(-1)}$ should be added to the steadystate model for pernitric acid.

[12] In an effort to determine the thermal decomposition rate, we assumed the $\mathrm{HO}_{2} \mathrm{NO}_{2}$ deposition loss frequency was equal to that of $\mathrm{HNO}_{3}$. Pernitric acid has been observed to readily adsorb on ice [Li et al., 1996], and it seems reasonable to expect deposition behavior similar to that of nitric acid. Given their high sticking probabilities [Li et al., 1996; Diehl et al., 1995; Abbatt, 1997; Zondlo et al., 1997], uptake of both species is likely to be controlled by transport to the snow surface. An average $\mathrm{HNO}_{3}$ lifetime of $3.5 \mathrm{hr}$ (3.1 $\mathrm{hr}$ median) was calculated by dividing the measured concentrations by the instantaneous production rate when $\mathrm{HNO}_{3}$ was thought to be in steady state. Loss due to reaction with $\mathrm{OH}$ and photolysis was found to be negligible. The required dry deposition rate for $\mathrm{HNO}_{3}$ was found to be temperature dependent, as apparent in Figure 4, due to changing mixing depths as discussed above. Therefore, the first order dry deposition loss coefficient was defined as: $\mathrm{k}_{(4)}=-2 \times 10^{-5}(27+\mathrm{T})+7 \times 10^{-5} \mathrm{~s}^{-1}$ where $\mathrm{T}$ is temperature in degrees Celsius. The resulting mean $\mathrm{HNO}_{3}$ lifetime due to dry deposition using this equation is $3.9 \mathrm{hr}$ (median $3.2 \mathrm{hr}$ ), which compares well with the calculation above.

[13] Setting the $\mathrm{HO}_{2} \mathrm{NO}_{2}$ deposition lifetime equal to that of $\mathrm{HNO}_{3}$ allows us to put an upper limit on $\mathrm{k}_{(-1)}$. As shown in Figure 3, we found that multiplying $\mathrm{k}_{(-1)}$ by 1.5 , equivalent to dividing $\mathrm{K}_{\mathrm{eq}}$ by 1.5 , reproduced the observed data best, with the median predicted value just $1 \%$ smaller than observed (average 5\% larger). The 1st quartile was $30 \%$ smaller than the corresponding observations, and the 3rd quartile was $30 \%$ larger. Note that multiplying $\mathrm{k}_{(-1)}$ by 1.5 is equivalent, within $1 \%$ across our temperature range, to increasing the activation energy $\left(\mathrm{E}_{\mathrm{a}}\right)$ in the Arrhenius equation from $20134 \mathrm{cal} / \mathrm{mol}$ to $20332 \mathrm{cal} / \mathrm{mol}$.

[14] The possibility that flux from the snow might be a source of pernitric acid under certain conditions is not supported by the measurements. Addition of a snow source term would require $\mathrm{K}_{\mathrm{eq}}$ to be substantially smaller than the JPL recommendation, which is possible given the large uncertainty factor. However, as pernitric acid's thermal decomposition rate increases, its importance as a $\mathrm{NO}_{\mathrm{x}}$ source via reaction (-1) is amplified. Steady-state calculations using $\mathrm{k}_{(-1)} \times 3.3$ show that thermal decomposition of the observed $\mathrm{HO}_{2} \mathrm{NO}_{2}$ can account for all of the observed $\mathrm{NO}_{\mathrm{x}}$ at $-26^{\circ} \mathrm{C}$, and even more than the observed $\mathrm{NO}_{\mathrm{x}}$ would be produced at warmer temperatures. Changing $\mathrm{E}_{\mathrm{a}}$ for $\mathrm{k}_{(-1)}$ from $20134 \mathrm{cal} / \mathrm{mol}$ to $20717 \mathrm{cal} / \mathrm{mol}$ is equal to multiplying $\mathrm{k}_{(-1)}$ by $3.3 \pm 2 \%$ between $-23.5^{\circ} \mathrm{C}$ and $-31.5^{\circ} \mathrm{C}$.

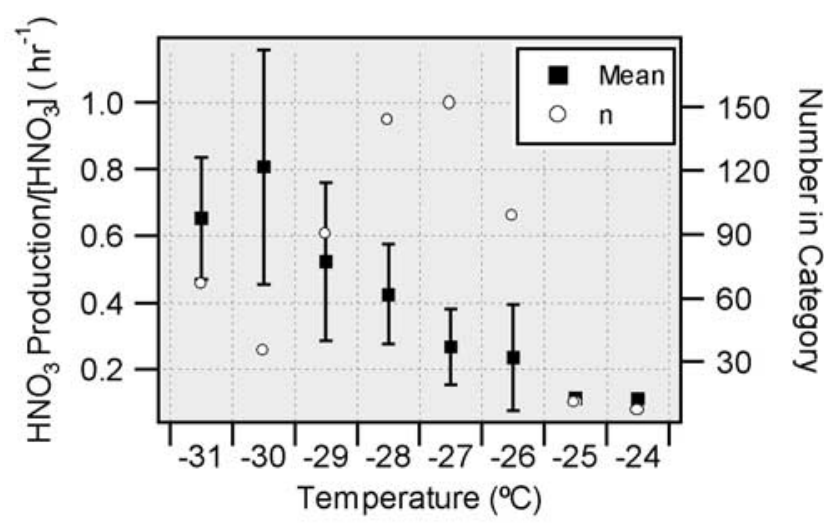

Figure 4. First order nitric acid loss as a function of temperature. Boxes represent the mean at each temperature and error bars span \pm 1 standard deviation. 
[15] A thermal decomposition rate this fast would require a transition from net deposition of $\mathrm{HO}_{2} \mathrm{NO}_{2}$ at temperatures $\leq-28^{\circ} \mathrm{C}$ to net flux out of the snow above $-28^{\circ} \mathrm{C}$ (see Figure 3) in order to maintain the observed $\mathrm{HO}_{2} \mathrm{NO}_{2}$ concentrations. Furthermore, the $\mathrm{NO}_{\mathrm{x}}$ flux from the snow must also cease at the transition point because all of the gas phase $\mathrm{NO}_{\mathrm{x}}$ would be produced by $\mathrm{HO}_{2} \mathrm{NO}_{2}$ decomposition alone. Since we know that sunlit snow emits $\mathrm{NO}_{\mathrm{x}}$ [Honrath et al., 1999], and a large, relatively constant $\mathrm{NO}_{\mathrm{x}}$ flux was measured during ISCAT 2000 [Davis et al., in preparation], we do not think this is a realistic scenario.

\section{Discussion and Conclusions}

[16] We believe that our data are only consistent with efficient deposition of $\mathrm{HO}_{2} \mathrm{NO}_{2}$ to the snow and that $\mathrm{k}_{(-1)} \times$ 3.3 [DeMore et al., 1997] is a firm upper limit to the thermal decomposition rate coefficient for pernitric acid between $-31.5^{\circ} \mathrm{C}$ and $-23.5^{\circ} \mathrm{C}$ based on our measurements and analysis. Consequently, it is likely that $\mathrm{HO}_{2} \mathrm{NO}_{2}$ is stable in other cold regions of the atmosphere. In order to get a more accurate assessment of $\mathrm{k}_{(-1)}$, measurements are needed in the free troposphere where deposition is not a factor.

[17] When pernitric acid and nitric acid are present in similar amounts in the South Pole boundary layer, as observed during ISCAT 2000, the two species should be approximately equally important $\mathrm{HO}_{\mathrm{x}}$ and $\mathrm{NO}_{\mathrm{x}}$ sinks due to dry deposition. However, pernitric acid dominates the $\mathrm{HO}_{\mathrm{x}}$ loss under these conditions due to its faster reaction with $\mathrm{OH}$ [DeMore et al., 1997]. The fact that a large fraction of the $\mathrm{NO}_{\mathrm{x}}$ is returned to the snow in the form of pernitric acid warrants a closer examination of the source(s) of $\mathrm{NO}_{\mathrm{x}}$ released from snow. Current understanding attributes the release of $\mathrm{NO}_{\mathrm{x}}$ from snowpack to the photolysis of $\mathrm{NO}_{3}^{-}$ [Honrath et al., 2000]. If pernitric acid remains intact on ice surfaces, as observed on pure water ice by Li et al. [1996], it has the potential to photodissociate, resulting in direct release of $\mathrm{NO}_{2}$. This might produce more efficient cycling of $\mathrm{NO}_{\mathrm{x}}$ between the snow and air than nitrate photolysis alone. $\mathrm{HO}_{2} \mathrm{NO}_{2}$ does have a larger gas phase absorption cross-section than $\mathrm{HNO}_{3}$ [DeMore et al., 1997] for wavelengths $>205 \mathrm{~nm}$. However, to our knowledge, the photochemistry of $\mathrm{HO}_{2} \mathrm{NO}_{2}$ and pernitrate, $\mathrm{NO}_{4}^{-}$, has not been determined on an ice surface or in aqueous solution.

[18] Pernitric acid deposited to the snow might also undergo other chemical transformations analogous to its behavior in aqueous solution (e.g., Regimbal and Mozurkewich [1997], and references within). Studies of pernitric acid photochemistry on ice and snow surfaces are needed in order to determine its significance as a $\mathrm{NO}_{\mathrm{x}}$ source. If pernitric acid photochemistry on and in snow does enhance $\mathrm{NO}_{\mathrm{x}}$ release into the atmosphere, it might be one of the factors that makes South Pole snowpack chemistry unique. Pernitric acid mixing ratios are probably much lower at other polar sites because of warmer temperatures and much lower $\mathrm{NO}_{\mathrm{x}}$ levels.

[19] Acknowledgments. We thank NOAA CMDL for $\mathrm{O}_{3}, \mathrm{CO}$, and meteorological data. We also appreciate the suggestions of two reviewers and Dr. Tom Ryerson. This work was funded by the NSF Office of Polar Programs and Division of Atmospheric Chemistry grant \# OPP-9725465 and NASA Earth Systems Science fellowship grant \# NGT5-30384.

\section{References}

Abbatt, J. P. D., Interaction of $\mathrm{HNO}_{3}$ with water-ice surfaces at temperatures of the free troposphere, Geophysical Research Letters, 24(12), 1479-1482, 1997.

Brune, W. H., et al., $\mathrm{OH}$ and $\mathrm{HO}_{2}$ chemistry in the North Atlantic free troposphere, Geophysical Research Letters, 26(20), 3077-3080, 1999.

Cantrell, C. A., R. E. Shetter, J. G. Calvert, F. L. Eisele, and D. J. Tanner, Some considerations of the origin of nighttime peroxy radicals observed in MLOPEX 2c, Journal of Geophysical Research, 102(D13), 15,89515,915, 1997.

Chen, G., et al., An investigation of South Pole HOx chemistry: Comparison of model results with ISCAT observations, Geophysical Research Letters, 28(19), 3633-3636, 2001.

Davis, D. D., et al., Unexpected high levels of NO observed at South Pole, Geophysical Research Letters, 28(19), 3625-3628, 2001.

DeMore, W. B., S. P. Sander, D. M. Golden, R. F. Hampson, M. J. Kurylo, C. J. Howard, A. R. Ravishankara, C. E. Kolb, and M. J. Molina, Chemical kinetics and photochemical data for use in stratospheric modeling, JPL Publication 97-4, 1997.

Diehl, K., S. K. Mitra, and H. R. Pruppacher, A laboratory study of the uptake of $\mathrm{HNO}_{3}$ and $\mathrm{HCl}$ vapor by snow crystals and ice spheres at temperatures between 0 and $-40^{\circ} \mathrm{C}$, Atmospheric Environment, 29(9), 975-981, 1995.

Graham, R. A., A. M. Winer, and J. N. Pitts, Jr., Temperature dependence of the unimolecular decomposition of pernitric acid and its atmospheric implications, Chemical Physics Letters, 51(2), 215-220, 1977.

Honrath, R. E., S. Guo, M. C. Peterson, M. P. Dziobak, J. E. Dibb, and M. A. Arsenault, Photochemical production of gas phase $\mathrm{NO}_{\mathrm{x}}$ from ice crystal $\mathrm{NO}_{3}$, Journal of Geophysical Research-Atmospheres, 105(D19), 24,183-24,190, 2000.

Honrath, R. E., M. C. Peterson, S. Guo, J. E. Dibb, P. B. Shepson, and B. Campbell, Evidence of $\mathrm{NO}_{\mathrm{x}}$ production within or upon ice particles in the Greenland snowpack, Geophysical Research Letters, 26(6), 695-698, 1999.

Jaeglé, L., D. J. Jacob, W. H. Brune, and P. O. Wennberg, Chemistry of $\mathrm{HO}_{\mathrm{x}}$ radicals in the upper troposphere, Atmospheric Environment, 35(3), 469-489, 2001

Jones, A. E., R. Weller, E. W. Wolff, and H.-W. Jacobi, Speciation and rate of photochemical NO and $\mathrm{NO}_{2}$ production in Antarctic snow, Geophysical Research Letters, 27(3), 345-348, 2000.

Lefer, B. L., S. R. Hall, L. Cinquini, and R. E. Shetter, Photolysis frequency measurements at the South Pole during ISCAT-98, Geophysical Research Letters, 28(19), 3637-3640, 2001.

Leibrock, E., and L. G. Huey, Ion chemistry for the detection of isoprene and other volatile organic compounds in ambient air, Geophysical Research Letters, 27(12), 1719-1722, 2000.

Li, Z., R. R. Friedl, S. B. Moore, and S. P. Sander, Interaction of peroxynitric acid with solid $\mathrm{H}_{2} \mathrm{O}$ ice, Journal of Geophysical Research, 101(D3), 6795-6802, 1996.

Mauldin, R. L., III, et al., Measurements of $\mathrm{OH}, \mathrm{H}_{2} \mathrm{SO}_{4}$, and MSA at the South Pole during ISCAT, Geophysical Research Letters, 28(19), 36293632, 2001.

Niki, H., P. D. Maker, C. M. Savage, and L. P. Breitenbach, Fourier transform IR spectroscopy observation of pernitric acid formed via $\mathrm{HOO}+$ $\mathrm{NO}_{2} \rightarrow \mathrm{HOONO}_{2}$, Chemical Physics Letters, 45(3), 564-566, 1977.

Regimbal, J. M., and M. Mozurkewich, Peroxynitric acid decay mechanisms and kinetics at low pH, Journal of Physical Chemistry A, 101(47), $8822-8829,1997$.

Ridley, B., et al., Is the Arctic surface layer a source and sink of $\mathrm{NO}_{\mathrm{x}}$ in winter/spring?, Journal of Atmospheric Chemistry, 36(1), 1-22, 2000.

Roehl, C. M., S. A. Nizkorodov, H. Zhang, G. A. Blake, and P. O. Wennberg, Photodissociation of peroxynitric acid in the near-IR, Journal of Physical Chemistry A, 106(15), 3766-3772, 2002.

Slusher, D. L., S. J. Pitteri, B. J. Haman, D. J. Tanner, and L. G. Huey, A chemical ionization technique for measurement of pernitric acid in the upper troposphere and the polar boundary layer, Geophysical Research Letters, 28(20), 3875-3878, 2001.

Wennberg, P. O., et al., Twilight observations suggest unknown sources of $\mathrm{HO}_{\mathrm{x}}$, Geophysical Research Letters, 26(10), 1373-1376, 1999.

Zondlo, M. A., S. B. Barone, and M. A. Tolbert, Uptake of $\mathrm{HNO}_{3}$ on ice under upper tropospheric conditions, Geophysical Research Letters, 24(11), 1391-1394, 1997.

L. G. Huey, School of Earth and Atmospheric Sciences, Georgia Institute of Technology, Atlanta, GA 30332, USA. (greg.huey@eas.gatech.edu) 